\title{
Acrylamide in food products - eating habits and consumer awareness among Medical School students
}

\author{
Małgorzata Kowalska', Anna Żbikowska², Sylwia Onacik-Gür'2, Dorota Kowalska ${ }^{3}$ \\ ${ }^{1}$ Faculty of Materials Science, Technology and Design, Department of Chemistry, University of Technology and \\ Humanities in Radom, Poland \\ ${ }^{2}$ Faculty of Food Science, Department of Food Technology, Warsaw University of Life Sciences (WULS-SGGW), Poland \\ ${ }^{3}$ Faculty of Food Sciences, Department of Chemistry, Warsaw University of Life Sciences (WULS-SGGW), Poland
}

Kowalska M, Żbikowska A, Onacik-Gür S, Kowalska D. Acrylamide in food products - eating habits and consumer awareness among Medical School students. Ann Agrice Environ Med. 2017; 24(4): 570-574. doi: 10.5604/12321966.1232764

\begin{abstract}
I Abstract
Introduction. Acrylamide is formed in several foods during high-temperature processing. In view of reports written about the neurotoxic, genotoxic and carcinogenic effects of acrylamide, it was considered that the presence of this substance in food products might pose a risk for human health. Currently, according to EU Commission recommendations, the content of acrylamide in food should be monitored.

Objective. The aim of this work was to analyze the food preferences of youth and students from medical schools in Radom, central-eastern Poland, as the most frequent precipitantsas in the field of food products that may be a significant source of acrylamide in the diet. Furthermore, an attempt was made to determine the level of knowledge of the population in the field of acrylamide.

Materials and method. The research was conducted by questionnaire. The study was based on the answers of 227 respondents. The survey was carried out by direct contact with an interviewer from February - June 2012.

Results. Analysis of the study population shows that women consume more coffee than men. In addition, adults over 25 years old consumed the largest quantity of coffee; it can therefore be assumed that it is a significant source of acrylamide in their bodies. However, even young people under 17 declared that they consume coffee every day (20\%).

Conclusions. Due to the adverse effects of this compound it is important to reduce the level of acrylamide in food products. A few people in the population (7\%) had heard of acrylamide previously, but none of them had any knowledge of its occurrence and formation. It is necessary to take strong action to change attitudes towards acrylamide and attempt to introduce ways to reduce this compound in the diet, for example, by appropriate selection of products in the daily diet and appropriate means of thermal preparation of products at home.
\end{abstract}

\section{Key words}

acrylamide, medical schools, processed food safety

\section{INTRODUCTION}

The topic of acrylamide in the diet appeared in 2002, when Swedish scientists discovered this chemical compound in cereal-based food products, as well as fried and baked potatoes [1]. In view of reports written about the neurotoxic, genotoxic and carcinogenic influence of acrylamide, it was considered that the presence of this substance in food products might pose a risk for human health $[2,3,4]$. Therefore, in May 2007, the EU Commission decided to monitor the level of acrylamide in food (2007/331/EC). Since 2 June 2010, new recommendations of the EU Commission have been adopted regarding the monitoring of acrylamide content in food. These actions were taken due to the fact that the monitoring programme did not bring the expected results. It was considered that the monitoring programme requires changes [5].

Address for correspondence: Małgorzata Kowalska, Faculty of Materials Science, Technology and Design, Kazimierz Pulaski University of Technology and Humanities in Radom, Poland

E-mail: mkowalska7@vp.pl

Received: 7 October 2013; accepted: 10 September 2014; first published on February 2017
Acrylamide is formed during high-temperature processing of food rich in carbohydrates, especially potatoes, cereal products and coffee $[6,7]$. It was shown that it is one of the products of the Maillard reaction, a reaction between free asparagine and reducing sugars (glucose, fructose) [8]. Structural considerations dictate that asparagine alone may be converted thermally into acrylamide through decarboxylation and deamination reactions. However, the main product of the thermal decomposition of asparagine was maleimide, mainly due to the fast intramolecular cyclization reaction that prevents the formation of acrylamide. On the other hand, asparagine, in the presence of reducing sugars, was able to generate acrylamide in addition to maleimide [9]. As mentioned above, one of the most important factors of acrylamide formation in food resources and intermediates, besides the quantitative reaction of reactants, is the temperature used in heat treatment. It was found that acrylamide is produced as a result of high temperature processing (from $120^{\circ} \mathrm{C}$ ). Moreover, it was shown that the duration of keeping food at such temperature might indeed affect the content of this chemical compound $[10,11,12]$.

In 2002, the World Health Organization evaluated the average exposure to acrylamide in food which ranged from $0.3-0.8 \mu \mathrm{g} / \mathrm{kg}$ b.m./day [13]. The amount of acrylamide in 
food depends on processing conditions, such as temperature, time, nature of the food matrix, oil or microwave use $[14,15]$. Mojska et al. [18] found the highest content of acrylamide in French fries $(63-2175 \mu \mathrm{g} / \mathrm{kg})$ and in potato chips (113$3647 \mu \mathrm{g} / \mathrm{kg}$ ) [18]. Similarly, Lasekan and Abbas [16] found very high acrylamide contents in heated carbohydrate-rich foods $(150-4,000 \mu \mathrm{g} / \mathrm{kg})$. Moreover, they found moderate levels of acrylamide in protein-rich foods $(5-50 \mu \mathrm{g} / \mathrm{kg})$ and lower levels in unheated or boiled foods $(5 \mu \mathrm{g} / \mathrm{kg})$. According to other authors, apart from the previously indicated sources in Poland, an important source of acrylamide are very popular breakfast cereals, which are regarded as a wholesome breakfast, and which are most often consumed by children at school age. These authors also found a significant level of acrylamide in crispbread $(65-1271 \mu \mathrm{g} / \mathrm{kg})$, crackers $(566-2017 \mu \mathrm{g} / \mathrm{kg})$ and daily consumed bread $(35-110 \mu \mathrm{g} / \mathrm{kg})$ $[17,18]$.

According to Zając et al. [19], elimination of acrylamide from a diet with proper and healthy nutrition is very unlikely. But others authors propose several methods to reduce the level of acrylamide based on biological, chemical and physical methods $[20,21]$.

\section{OBJECTIVE}

The aim of this study was to determine the level of knowledge on the subject of acrylamide among the study group, and products preferred by the respondents which might be a potential source of acrylamide in the diet, and the factors that influence the choice of the surveyed group. In the questionnaire, particular attention was paid to chips, French fries and coffee. The respondents were students from medical schools.

\section{MATERIAL AND METHODS}

The study was conducted through questionnaires which were completed by 227 school youths and students from a vocational school in Radom with a medical profile (paramedic, dental assistant, dental hygienist, pharmacy technician). The study was performed among people between the ages of 16-24 (most of the respondents) and 25-35. Characteristics of the population are shown in Table 1. The survey was carried out directly by an interviewer from February - June 2012.

Statistical analysis of the results was conducted by using statistical package Statistica PL for Windows v.5.5. The significance of differences in subgroups was estimated by the $\mathrm{Chi}^{2}$ test. The results were considered statistically significant at $\mathrm{p}<0.05$ for the two-sided test.

Table 1. Characteristics of the population

\begin{tabular}{lccccccccc}
\hline & \multicolumn{9}{c}{ Age } \\
\cline { 2 - 7 } Gender & \multicolumn{2}{c}{$16-17$} & \multicolumn{2}{c}{$18-24$} & \multicolumn{2}{c}{$25-35$} & \multicolumn{2}{c}{ Total } \\
\cline { 2 - 8 } & $\mathrm{n}$ & $\%$ & $\mathrm{n}$ & $\%$ & $\mathrm{n}$ & $\%$ & & $\%$ \\
\hline Females & 4 & 8.9 & 53 & 43.4 & 51 & 85.0 & 108 & 47.6 \\
\hline Males & 41 & 91.1 & 69 & 56.6 & 9 & 15.0 & 119 & 52.4 \\
\hline Total & 45 & 100.0 & 122 & 100.0 & 60 & 100.0 & 227 & 100.0 \\
\hline
\end{tabular}

When analyzing the differences between age subgroups, the biggest differences in the frequency of drinking coffee were observed between the mid-age group (14-18 years old) and the oldest (25-35), where $\mathrm{p}=0,000054$ (Tab. 2b). The oldest respondents consumed coffee with the highest frequency; $53 \%$ of them reported drinking this beverage every day. Nevertheless, some of them reported not consuming this product at all. Over $70 \%$ of respondents aged $16-17$ reported drinking coffee. The youngest subgroup and the oldest reported drinking coffee with similar frequency $(\mathrm{p}=0.91)$ (accurate probability $\mathrm{Chi}^{2}$ ) (Tab. 2b). 
Respondents reported consuming coffee in a generally moderate quantity. Over half of them limited their daily consumption to one cup (Fig. 1). According to Bekas et al. [23], people who drank coffee every day had a daily intake of acrylamide around $3.1 \mu \mathrm{g}$. On the other hand, people who consumed coffee a few times per week had an average daily intake of acrylamide of approximately $1.4 \mu \mathrm{g}$.

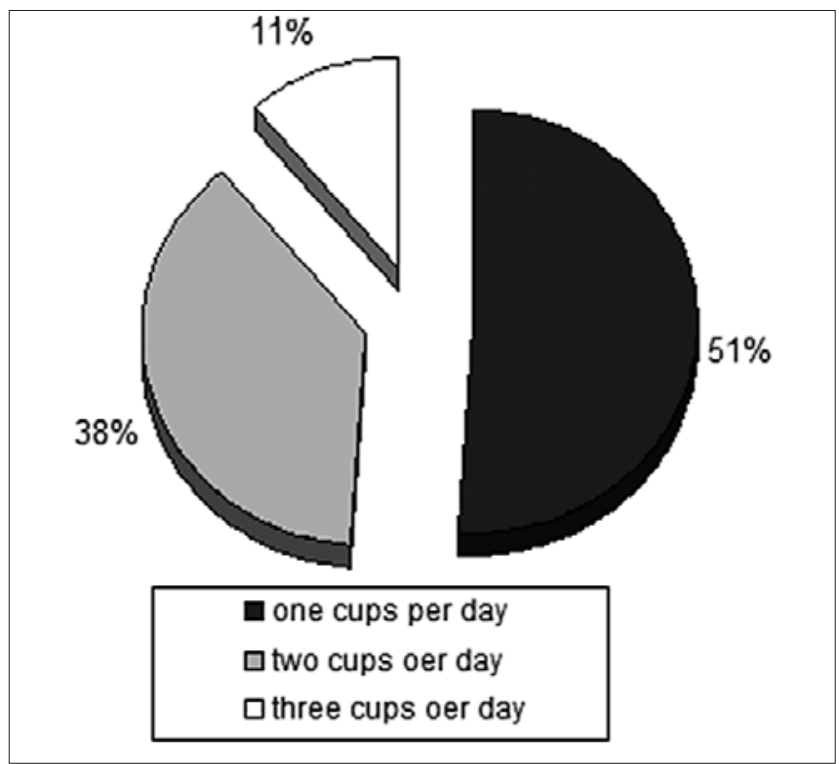

Figure 1. Amount of consumed coffee by the respondents during a day [\%]

Both men and women reported drinking coffee for similar reasons (Tab. 3a); those in the age range 18-24 consumed it mainly when they were tired (Tab. 3b). Similarly, the main reason for drinking coffee given by civil servants of central institutions in Warsaw was 'to overcome tiredness', while $35 \%$ of them stated that they drank coffee because they liked it [23].

Table 3. Reasons to drinking coffee a) by all respondents.

\begin{tabular}{lccccccc}
\hline & \multicolumn{4}{c}{ Gender } & \multicolumn{2}{c}{ Total } \\
\cline { 2 - 6 } Reasons for drinking coffee & \multicolumn{3}{c}{ Women $(\mathrm{n}=87)$} & \multicolumn{2}{c}{ Men $(\mathrm{n}=79)$} & \multirow{2}{*}{$\mathrm{n}$} & $\%$ \\
\cline { 2 - 6 } & $\mathrm{n}$ & $\%$ & $\mathrm{n}$ & $\%$ & & \\
\hline I like coffee & 37 & 42.5 & 37 & 46.8 & 74 & 44.6 \\
\hline It helps to defeat tiredness & 44 & 50.6 & 34 & 43.0 & 78 & 47.0 \\
\hline It is an element of social life & 10 & 11.5 & 7 & 8.9 & 17 & 10.2 \\
\hline No reason & 1 & 1.1 & 4 & 5.1 & 5 & 3.0 \\
\hline Total & 87 & 100.0 & 79 & 100.0 & 166 & 100.0
\end{tabular}

The percentages in columns do not add up to 100 because some respondents gave several reasons

b) depending on age

\begin{tabular}{lccccccccc}
\hline & \multicolumn{9}{c}{ Age } \\
\cline { 2 - 10 } Why do I drink coffee? & \multicolumn{1}{c}{$16-17$} & $18-24$ & $25-35$ & $\mathrm{n}$ & $\%$ \\
\cline { 2 - 10 } & $\mathrm{n}$ & $\%$ & $\mathrm{n}$ & $\%$ & $\mathrm{n}$ & $\%$ & & \\
\hline I like coffee & 17 & 51.5 & 32 & 38.1 & 25 & 51.0 & 74 & 44.6 \\
\hline It helps to defeat tiredness & 10 & 30.3 & 47 & 56.0 & 21 & 42.9 & 78 & 47.0 \\
\hline It is an element of social life & 6 & 18.2 & 6 & 7.1 & 5 & 10.2 & 17 & 10.2 \\
\hline No reason & 1 & 3.0 & 3 & 3.6 & 1 & 2.0 & 5 & 3.0 \\
\hline Total & 33 & 100.0 & 84 & 100.0 & 49 & 100.0 & 166 & 100.0
\end{tabular}

Another source of acrylamide in food, which was taken into consideration in this study, is potato chips. It was found that men and women consumed these kinds of products in moderate quantities. On average, they consumed chips a couple of times per month (Tab. $4 \mathrm{a})$. Men ate them more often ( $34 \%$ every day) than women ( $5 \%$ every day). Significant statistical differences in the frequency of chips consumption were found among age subgroups (16-17 and $25-35$; $18-24$ and 25-35) (Tab. 4b). Almost half of the respondents ate chips in small amounts: only one 100 g packet per month (Fig. 2). Bekas et al. [23] reported that $62 \%$ of civil servants consumed chips occasionally (less than once a month) or not at all, while only $3 \%$ ate them every day. Jankowska et al. [17] found that the global consumption of acrylamide in the paediatric population did not exceed $5 \%$.

Table 4. Frequency of chips consumption a) depending on gender

\begin{tabular}{lccccccc}
\hline \multirow{2}{*}{ Frequency } & \multicolumn{4}{c}{ Gender } & \multicolumn{3}{c}{ Total } \\
\cline { 2 - 6 } & \multicolumn{3}{c}{ Females } & \multicolumn{2}{c}{ Males } & \multirow{2}{*}{$\mathrm{n}$} & $\%$ \\
\cline { 2 - 6 } & $\mathrm{n}$ & $\%$ & $\mathrm{n}$ & $\%$ & & \\
\hline Not eating or sporadically & 7 & 8.0 & 6 & 7.6 & 13 & 7.8 \\
\hline Several times per month & 46 & 52.9 & 18 & 22.8 & 64 & 38.6 \\
\hline Several times per week & 30 & 34.5 & 28 & 35.4 & 58 & 34.9 \\
\hline Every day & 4 & 4.6 & 27 & 34.2 & 31 & 18.7 \\
\hline Total & 87 & 100.0 & 79 & 100.0 & 166 & 100.0
\end{tabular}

$\mathrm{p}<0,0001$.

b) depending on age

\begin{tabular}{|c|c|c|c|c|c|c|c|c|}
\hline \multirow{3}{*}{ Frequency } & \multicolumn{6}{|c|}{ Age } & \multirow{2}{*}{\multicolumn{2}{|c|}{ Total }} \\
\hline & \multicolumn{2}{|c|}{$16-17$} & \multicolumn{2}{|c|}{$18-24$} & \multicolumn{2}{|c|}{$25-35$} & & \\
\hline & $\mathrm{n}$ & $\%$ & $\mathrm{n}$ & $\%$ & $\mathrm{n}$ & $\%$ & $\mathrm{n}$ & $\%$ \\
\hline Never or sporadically & 10 & 30.3 & 30 & 35.7 & 37 & 75.5 & 77 & 46.4 \\
\hline Several times per month & 11 & 33.3 & 35 & 41.7 & 12 & 24.5 & 58 & 34.9 \\
\hline $\begin{array}{l}\text { Several times per week or } \\
\text { every day }\end{array}$ & 12 & 36.4 & 19 & 22.6 & 0 & 0 & 31 & 18.7 \\
\hline Total & 33 & 100.0 & 84 & 100.0 & 49 & 100.0 & 166 & 100.0 \\
\hline
\end{tabular}

Assessment of significance for full details: $p<0.0001$.

Significance of differences in subgroups:

age $16-17$ a $18-24: p=0.29$

age 16-17 a 25- 35: $\mathrm{p}<0.0001$

age 18-24 a $25-35: p<0.0001$

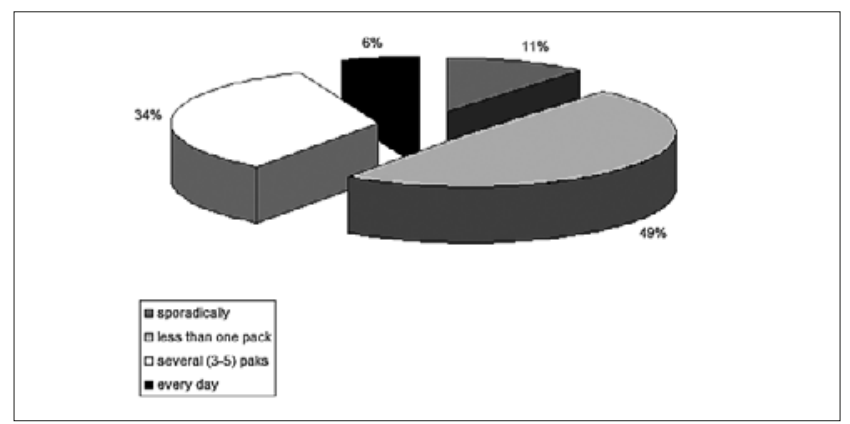

Figure 2. Quantity of consumed chips per month (100 g pack)

In the presented study, the frequency of French fries consumption was analyzed in the group of respondents. Men ate fries more often, most of them a couple of times a month (Tab. 5a). The great majority of women consumed French fries occasionally or not at all. The reason could be the popularity among women of maintaining a fit figure, 
Table 5. Frequency of French fries consumption a) depending on gender

\begin{tabular}{lccccccc}
\hline \multirow{2}{*}{$\begin{array}{l}\text { Frequency of French fries } \\
\text { consumption }\end{array}$} & \multicolumn{9}{c}{ Gender } & \multicolumn{3}{c}{ Total } \\
\cline { 2 - 8 } & \multicolumn{3}{c}{ Females } & \multicolumn{3}{c}{ Males } \\
\cline { 2 - 8 } & $\mathrm{n}$ & $\%$ & $\mathrm{n}$ & $\%$ & $\mathrm{n}$ & $\%$ \\
\hline Sporadically/never & 30 & 34.5 & 41 & 51.9 & 71 & 42.8 \\
\hline Several times per month & 4 & 4.6 & 6 & 7.6 & 10 & 6.0 \\
\hline Several times per year or every day & 87 & 100.0 & 79 & 100.0 & 166 & 100.0 \\
\hline Total & & & & & & \\
\hline $\mathrm{p}=0.0078$. & & & & & & \\
b) depending on age & & & & & &
\end{tabular}

\begin{tabular}{|c|c|c|c|c|c|c|c|c|}
\hline \multirow{3}{*}{$\begin{array}{l}\text { Frequency of French fries } \\
\text { consumption }\end{array}$} & \multicolumn{6}{|c|}{ Age } & \multicolumn{2}{|c|}{ Total } \\
\hline & \multicolumn{2}{|c|}{$16-17$} & \multicolumn{2}{|c|}{$18-24$} & \multicolumn{2}{|c|}{$25-35$} & \multirow[b]{2}{*}{$\mathrm{n}$} & \multirow[b]{2}{*}{$\%$} \\
\hline & $\mathrm{n}$ & $\%$ & $\mathrm{n}$ & $\%$ & $\mathrm{n}$ & $\%$ & & \\
\hline Sporadically/never & 10 & 30.3 & 37 & 44.0 & 38 & 77.6 & 85 & 51.2 \\
\hline $\begin{array}{l}\text { At least several times per } \\
\text { month }\end{array}$ & 23 & 69.7 & 47 & 56.0 & 11 & 22.0 & 81 & 48.8 \\
\hline Total & 33 & 100.0 & 84 & 100.0 & 49 & 100.0 & 166 & 100.0 \\
\hline
\end{tabular}

Assessment of significance for full details: $p<0.0001$

Significance of differences in subgroups:

age 16-17 a $18-24: p=0.06$.

age $16-17$ a $25-35: p<0.0001$

age $18-24$ a $25-35: p=0.00032$.

c) depending on the type groups of students

\begin{tabular}{lcccccc}
\multirow{2}{*}{$\begin{array}{l}\text { Frequency of French fries } \\
\text { consumption }\end{array}$} & \multicolumn{2}{c}{$\begin{array}{c}\text { School } \\
\text { youth }\end{array}$} & \multicolumn{2}{c}{$\begin{array}{c}\text { University } \\
\text { students }\end{array}$} & \multicolumn{2}{c}{ Total } \\
\cline { 2 - 8 } & $\mathrm{n}$ & $\%$ & $\mathrm{n}$ & $\%$ & $\mathrm{n}$ & $\%$ \\
\hline Sporadically/never & 30 & 36.6 & 55 & 65.5 & 85 & 51.2 \\
\hline Several times per month & 46 & 56.1 & 25 & 29.8 & 71 & 42.8 \\
\hline Several times per week or every day & 6 & 7.3 & 4 & 4.8 & 10 & 6.0 \\
\hline Total & 82 & 100.0 & 84 & 100.0 & 166 & 100.0 \\
\hline
\end{tabular}

$p=0.0032$.

controlling body weight, and paying more attention to a healthy lifestyle. Statistically significant differences were found in the frequency of French fries consumption among age categories $16-17$ and $25-35 ; 18-25$ and $25-35$ (Tab. 5b).

It was observed in the current study that among the older people the frequency of eating French fries was lower; therefore, the division into pupils and students is also presented to evaluate the difference between these groups(Tab. 5c). The division confirmed that university students consumed fewer French fries than pupils. It can be supposed that this situation may result from an increased consumer awareness of university students, or from better facilities in the form of canteens or cafeterias on the university campus.

Determination of the level of respondents' knowledge about acrylamide. Only $20 \%$ of respondents declared that when choosing a food product they consider the possible content of substances potentially harmful for the body. Most of the respondents (80\%) who answered negatively, unfortunately gave as a reason in their answer that they 'do not really care about it'. An affirmative answer was given mostly by women (65\%). People considering the possible content of harmful substances in products were mostly (approximately $90 \%)$ respondents in the age subgroup 25-35. This may indicate a higher consumer awareness among this group. Almost all of the respondents (90\%) claimed that they know potentially harmful substances occurring in food. Most of the respondents mentioned among the harmful substances, preservatives, synthetic flavours and aroma additives. In response to the question about knowledge of a harmful compound developing during the heat treatment of food, called 'acrylamide', only 7\% of those surveyed answered 'yes'. These people stated that they received this information from the Internet. Similar conclusions were reached by Zając et al. [19], who found that young people consume the highest amount of acrylamide. According to them, efforts should be made to increase their knowledge about the importance of nutrition and problems related to poor nutrition. There is still a need to promote a balanced diet and education aimed at selecting the proper products, regardless of age [17].

Over $50 \%$ of respondents thought it was essential to present information on the packages about even the smallest quantity of a chemical compound harmful for the body (Fig. 3). The respondents who did not see such a need argued that such food labeling would not affect their eating habits.
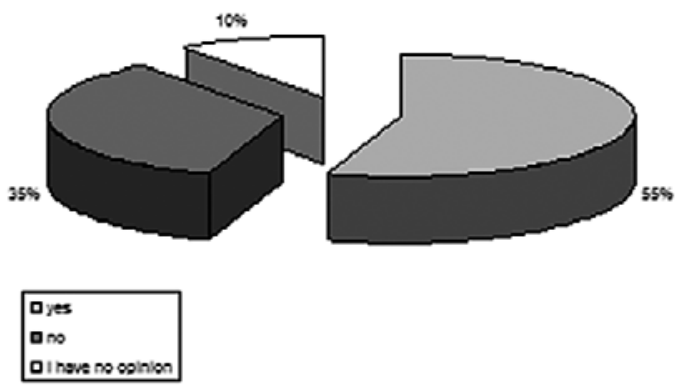

Figure 3. Structure of responses to the question: 'Should the information about the presence of even the smallest amount of potentially harmful substances be labeled?'

\section{CONCLUSION}

The results of the presented study clearly show that among the respondents, women studying in medical schools in Radom consume more coffee than men. Moreover, adults above 25 years of age drink the largest amount of coffee; therefore, it can be presumed that it is a significant source of acrylamide in their bodies. In turn, men, regardless of their age, more often consume chips and French fries. Concerning an unfavorable influence of this chemical compound, efforts should be made to reduce its content in food products.

A few respondents among the studied population (7\%) had heard about acrylamide before, but nobody from this group had knowledge of its occurrence and formation. Therefore, more effort should be made to educate people in Poland about acrylamide and teach them ways to reduce its intake; for example, the proper choice of products in the everyday diet or proper ways to prepare meals at home.

\section{REFERENCES}

1. Tareke E, Rydberg P, Karlsson P, Eriksson S, Tornqvist M. Analysis of Acrylamide, a Carcinogen Formed in Heated Foodstuffs. J Agric Food Chem. 2002; 50: 4998-5006.

2. Friedman M. Chemistry, Biochemistry and Safety of Acrylamide, A Review. J. Agric. Food Chem. 2003; 51: 4504-4526. 
3. Pelucchi C, La Vecchia C, Bosetti C, Boyle P, Boffetta P. Exposure to acrylamide and human cancer - a review and meta-analysis of epidemiologic studies. Ann Oncol. 2011; 22: 1487-1499.

4. Parka HR, Kima M-S, Kima SJ, Parka M, Konga KH, Kima HS, Kwackb SJ, Kangb TS, Kimb SH, Kima HS, Leea J. Acrylamide induces cell deathin neural progenitor cells and impairs hippocampal neurogenesis. Toxicol Lett. 2010; 193(1): 86-93.

5. Komisja Europejska 2010. Zalecenia Komisji z dnia 2 czerwca 2010 r w sprawie monitorowania poziomów akryloamidu w żywności (Tekst mający znaczenie dla EOG) (2010/307/UE), w szczególności jego art. 292 (in Polish).

6. Mojska H, Gielecińska I. Ocena narażenia dzieci i młodzieży na akryloamid obecny w produktach fast food i przekąskach.Prob.Hig Epidemiolo. 2012; 93(3) 613-67.

7. Zyzak DV, Sanders RA, Stojanovic M, Tallmadge DH, Eberhart BL, Ewald DK, et al. Acrylamide formation mechanism in heated foods. J Agric Food Chem. 2003; 51: 4782-4787.

8. Capuanoa E, Ferrignoa A, Acampaa I, Serpenb A, Açarb ÖÇ, Gökmenb $\mathrm{V}$, Foglianoa V. Effect of flour type on Maillard reaction and acrylamide formation during toasting of bread crisp model systems and mitigation strategies. Food Res Int. 2009; 42(9): 1295-1302.

9. Yaylayayan VA, Wnorowski A, Perez Locas C. Why Asparagine Needs Carbohydrates to Generate Acrylamide. J Agric Food Chem., 2003; 51: $1753-1757$.

10. Andrzejewski D, Roach JA, Gay ML, Musser SM. Analysis of coffee for the presence of acrylamide by LC-MS/MS. J. Agric. Food Chem. 2004; 52: 1996-2002.

11. Granby K, Fagt S. Analysis of acrylamide in coffee and dietary exposure to acrylamide from coffee. Analytica Chimica Acta, 2004; 520: 177-182.

12. Wenzl T, Calle MB, Anklam E. Analytical methods for determination of acrylamide on food products. a review. Food Additives and Contaminants, 2003; 20: 885-902.

13. Report of a Joint FAO/WHO. Consultation WHO Headquarters, Health implications of acrylamide in food; June 25-27 2002; Geneva, Switzerland; Geneva, WHO, 2002.
14. Yuan Y, Chen F, Zhao GH, Liu J, Zhang XH, Hu XSA. A comparative study of acrylamide formation induced by microwave and conventional heating methods. J Food Sci. 2007; 72(4): 212-216.

15. Sannya M, Jinapb S, Bakkerc EJ, van Boekela MA, Luninga PA. Possible causes of variation in acrylamide concentration in French fries prepared in food service establishments: An observational study. Food Chem. 2012; 132(1): 134-143

16. Lasekan O, Abbas K. Investigation of the roasting conditions with minimal acrylamide generation in tropical almond (Terminalia catappa) nuts by response surface methodology. Food Chem. 2010;125(2): 713-718

17. Jankowska J, Helbin J, Potocki A. Acrylamide as a foreign substance in food. Probl. Hig Epidemiolog. 2009; 90(2): 171-174 (in Polish).

18. Mojska H, Gielecińska I, Ołtarzewski M, Szponar L. Acrylamide exposure from foods of the Polish population. Bromat. Chem. Toksykol. 2009; 42: 436-441 (in Polish).

19. Zając J, Bojar I, Helbin J, Kolarzyk E, Potocki A, Strzemecka J, Owoc A. Dietary acrylamide exposure in chosen population of South Poland. Ann Agric Environ Med. 2013; 20(2): 351-355.

20. Rachwał D, Nebesny E. Reduction of acrylamide content in food products. Bromat. Chem. Toksykol. 2012; 45: 219-227 (in Polish).

21. Pyrzanowski K, Michałowicz J, Pingot D, Bukowska B. Charakterystyka metod biologicznych chemicznych i fizycznych ograniczających obecność akryloamidu w żywności Bromat. Chem. Toksykol. 2013; XLVI, (2): 216-224 (in Polish).

22. Hoffmann K, Bryl W, Marcinkowski JT, Rzesoś A, Wojtyła E, PupekMusialik D. Dietary behaviours of adolescents from urban and rural areas in the district of Szamotuły - a preliminary study. Ann Agric Environ Med. 2012; 19(1): 103-107.

23. Bekas W, Kowalska D, Łobacz M, Kowalski B. Dietary acrylamide intake by representatives of selected group of white collar worker. Bromat. Chem. Toksykol. 2009; 42(3): 491-497 (in Polish). 